\title{
Nature Management Conflicts in the Kaliningrad Region
}

\author{
Viktor P. Dedkov* \\ Svetlana M. Nikitina \\ Immanuel Kant Baltic Federal University, Russian Federation \\ Corresponding Email: VDedkov@kantiana.ru
}

Doi:10.5901/mjss.2015.v6n6s7p67

\begin{abstract}
To meet the Kaliningrad region's sustainable development challenges it is necessary to mitigate the existing nature management conflicts locally. To identify them, a landscape planning methodology very common in Germany was used. The conducted international research made it possible to identify very acute, moderately acute conflicts and some areas representing weak conflicts or no conflicts. The examples of various types of territories are given. Recommendations to mitigate the existing nature management conflicts and prevent any new ones in the region are given.
\end{abstract}

Keywords: Kaliningrad region, natural management conflict, sustainable development, landscape planning

\section{Introduction}

Sustainable development is a vital principle to any territory (Agenda 21, 1993). That is a priority in the Kaliningrad region's strategic and spatial planning. With regard to the conditions of the densely populated and economically transformed Kaliningrad region, it is quite essential to reduce the degree of conflictogenity between economic development and nature protection. Addressing sustainable development issues can be backed by spatial, territorial, and especially environmentally oriented landscape planning. This is a communicative process involving all the stakeholders in the environmental and economic activities and contributing to identification of the interests of natural resource users, nature-related problems and conflicts as well as elaboration of solutions to conflicts and development of the coordinated action plan and activities.

Germany achieved considerable success in landscape planning. Supported by the German partners the Institute of Geography of the Siberian Branch of the Russian Academy of Sciences performed landscape planning in the Baikal region. The experience was used and further developed by scientists of the I. Kant BFU in identifying of conflict reduction issues territories in the Kaliningrad region (Köppel et al., 2004; Landesentwicklungsplan, 2003; Antipov et al., 2005; Guidelines, 2000; Guidelines, 2001; Antipov et al., 2002). solutions.

The article covers the classification of nature management conflicts in the Kaliningrad region and suggests

\section{Classification of Nature Management Conflicts}

The intensive reclamation and dense population of the Kaliningrad region (population density is 64 people per sq. $\mathrm{km}$ ) lead to a high rate of actual and potential nature management conflicts there. $A$ nature management conflict is a contradiction of the territorial priorities in nature protection and economic development within a particular mode of nature management being expressed in the actual or potential degradation of natural systems of a territory or their main components, decrease in the diversity, productivity and value of landscapes as well as the overall effectiveness of the implementation of economic functions of the territory.

There can be identified both actual and potential nature management conflicts. The real (i.e. existing) conflict in nature management is characterised by the presently available negative consequences caused by the anthropogenic transformation of the environment and manifested primarily in the pollution of ecosystems, depletion of natural resources and degradation of natural landscapes, biodiversity loss and leading to the deterioration in health, operational conditions of the equipment, deterioration in quality and reduction of the production of various branches of natural resources.

The potential conflict in nature management is characterised by contradictions in the environmental protection and 
economic development priorities without the currently expressed negative effects caused by the anthropogenic transformation of the environment. With an increase in intensity of nature management or loss of effectiveness of the conservation measures there is a high probability that a potential conflict will become a real one.

By degree of severity, conflicts are generally divided into three categories, namely: very acute, acute and moderately acute.

\section{Nature Management Conflicts in the Kaliningrad Region}

The classification of nature management conflicts in the Kaliningrad region is given Table 1.

Table 1. Conflict categories

\begin{tabular}{|c|c|c|c|}
\hline Category & Description of conflict & Manifestation features & Examples of conflict \\
\hline \multicolumn{4}{|l|}{ Conflict territories } \\
\hline Very acute conflict & $\begin{array}{l}\text { Polarity of priorities, pronounced contradiction of } \\
\text { development objectives for the territory. } \\
\text { Deep and robust anthropogenic transformation } \\
\text { of the natural systems and lithogenic bases of } \\
\text { landscapes, the substitution of natural } \\
\text { components of man-made structures, availability } \\
\text { of disturbed territories large by area. } \\
\text { Irreversibility of natural seral processes }\end{array}$ & $\begin{array}{l}\text { Acute contamination of soil, air and } \\
\text { water as a result of urbanisation and } \\
\text { industrial production, open-pit operation } \\
\text { of amber, forest and subsurface } \\
\text { resources management, recreation }\end{array}$ & $\begin{array}{l}\text { Town of Zelenogradsk and its } \\
\text { environs, Zelau ecosystem, the } \\
\text { river Pregolya in the lower } \\
\text { reaches, Yantarny village }\end{array}$ \\
\hline $\begin{array}{l}\text { Moderately acute } \\
\text { conflict }\end{array}$ & $\begin{array}{l}\text { Available contradictions in the development } \\
\text { objectives for individual natural components, } \\
\text { locally extensive development in the } \\
\text { environmental respect of significant natural } \\
\text { components. } \\
\text { Moderate anthropogenic transformation of } \\
\text { individual natural components without changing } \\
\text { the lithogenic bases of landscapes. The } \\
\text { possibility of full recovery of natural systems and } \\
\text { the stabilisation of the environmental situation in } \\
\text { the reduction or termination of the anthropogenic } \\
\text { pressure. }\end{array}$ & $\begin{array}{l}\text { Soil disturbance as a result of mining. } \\
\text { Disturbance of forest management. } \\
\text { Pollution and disturbance of the natural } \\
\text { environment as a result of recreational } \\
\text { activities. Storage of waste including the } \\
\text { unauthorised storage. Environmental } \\
\text { contamination by the industrial } \\
\text { discharges and emissions. Violation of } \\
\text { the environmental standards in } \\
\text { agriculture }\end{array}$ & $\begin{array}{l}\text { The Neman forest, Kaliningrad } \\
\text { Diversion Channel and } \\
\text { Primorskaya Bay, Vistula Spit, } \\
\text { the interfluve area of the rivers } \\
\text { Severnaya and Dalnaya, } \\
\text { upstream the river Pregolya in } \\
\text { the area of Chernyakhovsk } \\
\text { town, National Park Curonian } \\
\text { Spit }\end{array}$ \\
\hline \multicolumn{4}{|c|}{ Relatively conflict-free territories } \\
\hline $\begin{array}{l}\text { Weak conflict or no } \\
\text { conflict }\end{array}$ & $\begin{array}{l}\text { The lack of pronounced contradictions } \\
\text { associated with the development of a territory } \\
\text { and the relatively balanced development. } \\
\text { Weak anthropogenic transformation of the } \\
\text { natural components of geosystems, their } \\
\text { changes are easily reversible in reducing } \\
\text { anthropogenic pressures; the environmental } \\
\text { pollution does not exceed the permissible values }\end{array}$ & $\begin{array}{l}\text { Local disturbances in the shape of the } \\
\text { landscape as a result of irrational } \\
\text { conduct of activities }\end{array}$ & \\
\hline
\end{tabular}

To select categories of conflict, three types of criteria ranked by the degree of their manifestations are adopted:

- the degree of compatibility of the territorial environmental protection and economic development priorities within a particular mode of nature;

- the degree of anthropogenic transformation of the natural components of a territory;

- the degree of reversibility (recovery) of the anthropogenic transformation of natural systems.

In determining the category of a conflict, not only severity but also the duration and frequency of a conflict are of fundamental importance. In this respect, conflicts can be permanent, long, seasonal, occasional or episodic.

The real nature management conflicts identified in the Kaliningrad region are usually associated with the mining effects (construction materials, peat and oil), unauthorised forest felling and violations of plant associations, pollution and human-induced changes in river channels, development of the water and erosion phenomena and overgrazing. It is typical for territories with the revealed real conflicts as follows: 
Table 2. The area ratio of various categories of conflict

\begin{tabular}{clcc}
\hline No & Category of conflict & Land area $\left(\mathbf{k m}^{2}\right)$ & Share (in \%) \\
\hline 1. & Very acute & 196.7 & 1.4 \\
2. & Acute & 713.3 & 5.4 \\
3. & Moderately acute & $2,171.6$ & 16.3 \\
4. & Relatively conflict-free & $10,218.4$ & 76.9 \\
\hline & Total & 13,300 & 100 \\
\hline
\end{tabular}

Source: (Dedkov, 2006).

- the local distribution

- the sustainable anthropogenic transformation of natural sites, the availability of disturbed areas;

- the irreversibility of the natural seral processes;

- the relevance of environmental issues;

- the need for a comprehensive reclamation of disturbed areas.

As an area of a potential nature management conflict of identified are some sites, which are developing relatively well, with various degrees of the anthropogenic transformation of natural systems connected with the real prospect of intensive economic development of the natural components and systems most valuable in the environmental respect and sensitive to human impact.

A review of the nature management conflicts identified in the Kaliningrad region has shown that they are mainly related to the areas of nature management, such as urbanisation, peat mining, storage of the municipal solid waste, forest management, water management, recreation, subsurface resources management and agriculture. In addition, some territories are identified where the conflict development is associated with several types of nature management and the contradictions between them.

By the degree of nature management conflict severity, two types of territories have been identified, i.e. conflictrelated (with a predominance of very acute, acute and moderately acute conflicts) and relatively conflict-free (with a predominance of weak conflicts or lack thereof). Most of the territory is characterised as relatively conflict-free ( $76.9 \%$ of the territory) or moderately conflict (16.3\% of the territory). The agricultural land is mostly attributed to a group of the least conflict territories.

The areas of acute and very acute nature management conflicts (5.4 and $1.4 \%$ of the region's territory respectively) are related to the consequences of the development of urban centres in the Kaliningrad region, disturbances of the mode of forest management, subsurface resources management and water use schedules as well as recreational activities.

For the areas of real nature management conflicts, in which the need to resolve a conflict situation is most acute, researchers of the I. Kant BFU developed passports with an indication of the type and nature of the conflict, participants (parties to) of the conflict and proposals to mitigate the conflict. Appropriate measures should be offered in the Kaliningrad region's landscape programme which should be given the status of a binding document in the region.

\section{Conclusion}

The priorities of eliminating nature management conflicts in the Kaliningrad region are as follows:

Approval of the landscape programme as the basis for the territory's strategic planning and environmentallyoriented use of natural resources in the region through a decree of the governor of the Kaliningrad region;

Improvement of the legal framework governing the administration and functioning of natural areas of preferential protection at the regional and local levels (including the preparation and approval of the law of the Kaliningrad region 'On the Procedure for Classifying Land as the Land of Natural Areas of Preferential Protection of the Regional and Local Status');

Establishment of the Department of Management of the Natural Areas of Preferential Protection in the Kaliningrad Regional Government;

Organisation of the first phase of a regional network of natural areas of preferential protection (natural frame cores) and optimisation of their operation: expansion of borders and tightening of the regime of protection of the Curonian Spit National Park; preparation of feasibility studies for the creation of federal natural areas of preferential protection, the State Nature Reserve Pravdinsky, i.e. the Ozersk forest and Zelau swamp; the Vistula Spit, a branch of the Natural National 
Park Curonian Spit; creation of a network of landscape (integrated) reserves, i.e. Vishtynetsky Forest, i.e. the forest area Krasny (Red) with surrounding territories (an integrated reserve with a view to create a cross-border natural park); Dunny, the forest area Dalny, swamp Kozye, river Dalnyaya and surrounding areas in the delta of the river Neman (an integrated reserve with a view to the creation of a cross-border natural park); Gromovsky, the forest area Gromovsky and Large Moss bog (an integrated reserve); Kornevsky, the forest area Zimovnik with part of the Kornevka river basin (an integrated reserve); Kamensky, the forest and bog area (an integrated reserve); Balga, the coastal wetland area (an integrated reserve).

Development and implementation of regional programmes for the environmentally oriented forest management (including the rehabilitation of forest communities in the watersheds and along the river valleys);

Remediation and reclamation of areas disturbed during the economic activities, i.e. amber, sand and gravel quarries, cattle burial grounds, dumps, riverbeds and the banks of the most polluted waterways;

Creation of a network of sewage treatment plants (including those of the plant-swamp type);

Development and implementation of programmes to protect soil on the areas of the formation of surface and groundwater runoff;

Development and implementation of the regional programme for ecological tourism.

\section{References}

Agenda 21: Programme of Action for Sustainable Development (1993). Rio Declaration on Environment and Development. Rio de Janeiro, Brazil. United Nations Department of Public Information.

Antipov, A.N., Kravchenko, V.V., \& Semenov, Yu.M (2005). Landscape planning: Tools and Application Experience. Irkutsk: Publishers of the Institute of Geography of the Siberian Branch of the Russian Academy of Sciences.

Antipov, A.N., Plyusnin, V.M., \& Bazhenova, O.N. (2002). Environmentally Oriented Planning of Land Use in the Baikal Region. Baikal Natural Territory. Irkutsk: Publishers of the Institute of Geography of the Siberian Branch of the Russian Academy of Sciences.

Dedkov, V.P., \& Fedorov, G.M. (2006). Spatial, Territorial and Landscape Planning in the Kaliningrad Region. Kaliningrad: Publishers of the I. Kant RGU.

Guidelines for Landscape Planning. T. I. (2000). A.V. Drozdov (ed.). Moscow.

Guidelines for Landscape Planning. T. II. (2001). Guidelines for Landscape Planning. Moscow: National Centre for Environmental Programmes.

Köppel, J., Peters, W., \& Wende, W. (2004). Eingriffsregelung. Umveltverträglichkeitsprüfung. FFH-Verträglichkeitsprüfung. - Stuttgart: Verlag Eugen Ulmer.

Landesentwicklungsplan Sachsen (2003). Sächsisches Landesamt für Umwelt und Geologie. Dresden. 